\title{
IMPLEMENTASI PROGRAM KERJA PKK (PEMBERDAYAAN DAN KESEJAHTERAAN KELUARGA) DALAM PEMBERDAYAAN EKONOMI RUMAH TANGGA DI DESA RATNA CHATON KECAMATAN SEPUTIH RAMAN KABUPATEN LAMPUNG TENGAH
}

\author{
Destri Rahmawati \\ Institut Agama Islam Agus Salim Metro \\ Jl. Brigjend. Sutiyoso No. 7, Kota Metro, 34111, Lampung \\ destrirahawati757@yahoo.com
}

\begin{abstract}
This study discusses the Implementation of PKK (Empowerment and Family Welfare) Work Program in household economic empowerment in Ratna Chaton Village, Seputih Raman District, Central Lampung Regency. This research includes field research (Field Research) which is a study conducted systematically by raising the data in the field. While its nature is descriptive, that is to make a picture or painting systematically, factually, and accurately about the facts, the characteristics and the relationship between the phenomena under investigation. In collecting data using the interview method, observation method and documentation method. The authors' research findings show that the implementation of the PKK work program in household economic empowerment in the Ratna Chaton Village of Seputih Raman District through the UPPK (Family Revenue Improvement Efforts) program has led to a successful economic empowerment program, the implementation of which is entrepreneurship training, venture capital lending, and developing productive household businesses. Housewives experience changes by being able to explore the abilities they have, increasing living standards and housewives can be independent by developing their businesses and can generate household economic income.
\end{abstract}

Keywords: Household Economic Empowerment, PKK Program

\section{ABSTRAK}

Penelitian ini membahas mengenai Implementasi Program Kerja PKK (Pemberdayaan dan Kesejahteraan Keluarga) dalam pemberdayaan ekonomi rumah tangga di Desa Ratna Chaton Kecamatan Seputih Raman kabupaten Lampung Tengah. Penelitian ini termasuk penelitian lapangan(Field Research) yaitu suatu penelitian yang dilakukan secara sistematis dengan mengangkat data yang ada di lapangan. Sedangkan sifatnya adalah bersifat deskriptif yaitu untuk membuat gambaran atau lukisan secara sistematis, faktual, dan akurat mengenai fakta - fakta, sifat - sifat serta hubungan antara fenomena yang diselidiki. Dalam pengumpulan data yaitu menggunakan metode interview, metode observasi dan metode dokumentasi. Hasil temuan penelitian penulis menunjukkan bahwa implementasi program kerja PKK dalam pemberdayaan ekonomi rumah tangga di Desa Ratna Chaton Kecamatan Seputih Raman melalui program UPPK (Usaha Peningkatan Pendapatan Keluarga) pelaksanaan program kerja pemberdayaan ekonomi sudah berjalan dengan baik, pelaksanaanya yaitu pelatihan kewiraushaan, peminjaman modal usaha, dan pengembangan usaha produktif rumah tangga. Ibu rumah tangga mengalami perubahan dengan dapat menggali kemampuankemampuan yang mereka miliki, meningkatnya taraf hidup serta ibu rumah tangga dapat 
mandiri dengan mengembangkan usahanya dan dapat menghasilkan pendapatan ekonomi rumah tangga.

\section{Kata Kunci :Pemberdayaan Ekonomi Rumah Tangga, Program PKK}

\section{Pendahuluan}

Pemberdayaan dapat disamakan dengan istilah pengembangan atau pembangunan. Pemberdayaan berasal dari kata daya yang berarti kekuatan. Jadi pemberdayaan berarti upaya untuk memperoleh kekuatan dalam menguatkan diri dari segala bentuk penindasan.(Machendrawaty,2001:97).

Pemberdayaan adalah upaya untuk membangun kemampuan masyarakat,dengan mendorong, memotivasi, membangkitkan kesadaran akan potensi yang dimiliki dan berupaya untuk mengembangkan potensi itu menjadi tindakan nyata. Pemberdayaan masyarakat pada dasarnya merupakan proses untuk membuat masyarakat menjadi berdaya. Setiap anggota masyarakat dalam sebuah komunitas sebenarnya memiliki potensi, gagasan serta kemampuan untuk membawa dirinya dan komunitasnya untuk menuju ke arah yang lebih baik, namun potensi itu terkadang tidak bisa berkembang disebabkan faktorfaktor tertentu. Untuk menggerakkan kembali kemandirian masyarakat dalam pembangunan di komunitasnya, maka diperlukan dorongan-dorongan atau gagasan awal untuk menyadarkan kembali peran dan posisinya dalam kerangka untuk membangun masyarakat madani. Proses penyadaran masyarakat tersebut dilakukan melalui konsep-konsep pengembangan kapasitas. Pengembangan kapasitas masyarakat adalah bentuk dari upaya pengembangan pengetahuan, sikap dan keterampilan masyarakat agar dapat berperan serta aktif menjalankan pembangunan secara mandiri dan berkelanjutan.

Pemberdayaan masyarakat adalah upaya untuk meningkatkan harkat martabat golongan masyarakat yang sedang dalam kondisi miskin, sehingga mereka dapat melepaskan diri dari perangkap kemiskinan dan keterbelakangan. (Zubaidi,2013:24)

Pemberdayaan masyarakat tidak hanya mengembangkan potensi ekonomi rakyat, tetapi juga harkat dan martabat, rasa percaya diri dan harga dirinya, terpeliharanya tatanan nilai budaya setempat.

Dalam Al-Qur' an Surat Huud : 11/61

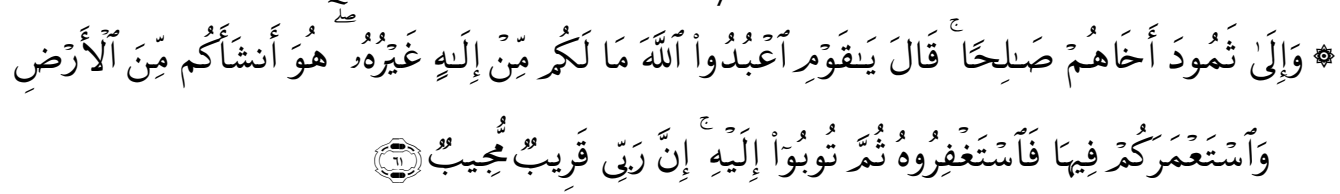

Artinya : Dan kepada kaum Tsamud (Kami utus) saudara mereka shaleh. Shaleh berkata: "Wahai kaumku, sembahlah Allah, tidak ada Tuhan bagimu selain Dia. Dia Telah menciptakan kamu dari bumi (tanah) dan menjadikan kamu pemakmurnya, Karena itu mohonlah ampunan-Nya, Kemudian bertobatlah kepada-Nya, Sesungguhnya Tuhanku sangat dekat (rahmat-Nya) lagi memperkenankan (doa hamba-Nya).( Q.S. Huud: 61). ( Departemen RI, Al-Qur'an Terjemah Indonesia,2005:420)

Telah jelas Allah menciptakan kita dibumi ini adalah untuk memakmurkan bumi ini, yaitu mengelola sumber daya alam yang ada untuk dimanfaatkan demi kemaslahatan. Dalam surat Al-Hadid ayat 25 disebutkan juga : 


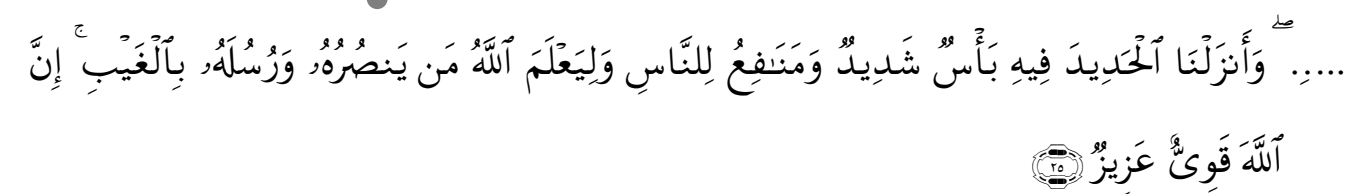

Artinya :.....Dan kami menciptakan besi (dan perak, emas, aluminium, tembaga , minyak dll) yang padanya terdapat kekuatan yang hebat dan berbagai manfaat bagi manusia, (supaya mereka mempergunakan itu/dapat diolah) dan supaya Allah mengetahui siapa yang menolong (agama)Nya dan rasul-rasul-Nya padahal Allah tidak dilihatnya. Sesungguhnya Allah Maha Kuat lagi Maha Perkasa.(Q.S. Al-Hadid;25)

Setiap Muslim yang patuh kepada Allah wajib bekerja keras mengolah bahan baku seperti : perak, minyak, emas, tembaga dll menjadi macm-macam barang yang berguna ,sehingga dapat digunakan untuk kemaslahatan umat.

Pemberdayaan sebagai konsep sosial budaya yang implementatif dalam pembangunan yang berpusat pada rakyat, tidak saja menumbuhkan dan mengembangkan nilai tambah ekonomi, tetapi juga nilai tambah sosial dan budaya. Pemberdayaan dan partisipasi merupakan hal yang menjadi pusat perhatian dalam proses pembangunan. Pemberdayaan dan partisipasi merupakan strategi yang sangat potensial dalam rangka meningkatkan ekonomi, sosial dan transformasi budaya. Proses ini pada akhirnya akan dapat menciptakan pembangunan yang lebih berpusat pada rakyat. Dalam hal ini cara terbaik untuk mengatasi masalah pembangunan adalah membiarkan semangat wiraswasta tumbuh dalam kehidupan masyarakat berani mengambil resiko, berani bersaing, menumbuhkan semangat bersaing, dan menemukan hal-hal baru(inovasi) melalui partisipasi masyarakat. (Harry Hikmat,2006;4)

Kegiatan pemberdayaan masyarakat merupakan salah satu kegiatan yang efektif dalam rangka memandirikan dan memberdayakan masyarakat tentunya. Kegiatan tersebut dapat dilakukan kapanpun, dimanapun dan oleh siapapun. Pada dasarnya kegiatan pemberdayaan masyarakat ditujukkan untuk kalangan masyarakat yang kurang mampu, agar dapat memandirikan mereka, guna membuat mereka dapat menolong dirinya sendiri.

Pemberdayaan ekonomi adalah upaya untuk membangun daya (masyarakat) dengan mendorong, memotivasi, dan membangkitkan kesadaran akan potensi ekonomi yang dimilikinya sehingga mampu memanfaatkan peluang- peluang ekonomi yang ada serta berupaya untuk mengembangkannya . Keberdayaan masyarakat adalah unsur dasar yang memungkinkan suatu masyarakat bertahan.

Melihat urgensi pentingnya pemberdayaan masyarakat saat ini, maka pemberdayaan dan pelayaan khusus bagi masyarakat menjadi prioritas yang utama dalam meningkatkan kesejahteraan masyarakat. Harapan masa depan adalah pentingnya perlakuan atau pelayanan yang terbaik pada masyarakat untuk mencapai tingkat kehidupan yang lebih baik (sejahtera).

Sejauh ini, sebenanrnya berbagai kalangan telah merintis upaya pemberdayaan masyarakat diberbagai bidang kegiatan seperti pemberdayaan ekonomi rakyat, pengentasan kemiskinan, pemeberdayaan perempuan, pemberdayaan masyarakat, pemberdayaan pendidikan, kesehatan, pemulihan sosial ekonomi masyarakat akibat konflik dan sebaginya.

PKK (Pemberdayaan Kesejahteraan Keluarga) merupakan wadah bagi perempuan untuk mengembangkan kemampuan dan potensi yang dimiliki 
perempuan agar secara mandiri mempunyai keterampilan dan keahlian dalam mengatasi masalah yang mereka hadapi secara mandiri melalui peningkatan kapasitas dan kualitas hidup. PKK yang merekrut anggota sampai lapisan bawah masyarakat diharapkan mampu membawa pada kondisi keluarga yang sejahtera, yaitu keluarga yang mampu memenuhi kebutuhan dasar manusia baik secara material, sosial, mental dan spiritual serta keluarga yang berdaya yaitu keluarga yang hidup sejahtera, maju dan mandiri. Selain itu, PKK diharapkan mampu membebaskan perempuan dari belenggu budaya patriarkhi, sehingga memiliki kemandirian. Melalui PKK diharapkan harkat dan martabat perempuan sebagai bagian dari keluarga dapat ditingkatkan. Dari sisi programnya, PKK diarahkan untuk mendorong kemajuan perempuan agar dapat memainkan peran gandanya secara baik, yaitu sebagai pengelola keluarga, pencari nafkah dan pelaku pembangunan. Dengan demikian sasarannya ditujukan untuk mengembangkan dan mengangkat berbagai potensi yang ada pada diri perempuan yang memungkinkan dirinya dapat memanfaatkan hak dan kesempatan yang sama terhadap sumber pembangunan (Biro Pemberdayaan Perempuan Kementerian Peranan Wanita, 2007).

Dalam kehidupan nyata seringkali perempuan kurang mampu berperan aktif dalam ekonomi keluarga, sehingga perempuan hanya bekerja sebagai ibu rumah tangga dan bergantung dengan hasil pendapatan suami. Pekerjaan perempuan dalam rumah tangga menyebabkan perempuan dianggap sebagai penerima pasif pembangunan. Dalam rangka mendorong partisipasi perempuan dalam pembangunan perlu terus makin dikembangkan kegiatan perempuan dalam meningkatkan kesejahteraan keluarga antara lain melalui organisasi Pemberdayaan Dan Kesejahteraan Keluarga PKK.

Kesejahteraan keluarga menjadi tujuan utama PKK. Hal ini dikarenakan keluarga merupakan unit terkecil masyarakat yang akan berpengaruh besar terhadap kinerja pembangunan. Dengan basis keterampilan yang dimiliki seyogyanya organisasi PKK mampu membekali masyarakat dengan berbagai jenis keterampilan, dan dengan potensi kodrati kewanitaan yang dimiliki organisasi ini diharapkan mampu mengajak dan membimbing masyarakat untuk terus belajar dalam rangka peningkatan kualitas hidup masyarakat.

Tuntutan akan fleksibilitas PKK untuk menjadi agen pembangunan dan agen perubahan semakin kuat. Munculnya krisis ekonomi global dan lingkungan hidup (eco system) yang harus diatasi oleh pemerintah, menjadikan organisasi PKK sebagai agen pembangunan dan agen perubahan terdepan dalam peningkatan kesejahteraan keluarga. Kiprah PKK di lingkungan masyarakat juga merupakan salah satu ikon bergeraknya civil society dalam peningkatan kesejahteraan keluarga dan lebih terasakan efektivitasnya dengan adanya kaderkader yang menjangkau sampai di tingkat Desa/Kelurahan.

PKK (Pemberdayaan Kesejahteraan Keluarga) memiliki sepuluh program PKK yaitu Penghayatan dan pengamalan pancasila, gotong royong, pangan, sandang. perumahan dan tata laksana rumah tangga, pendidikan dan keterampilan, kesehatan, pengembangan kehidupan berkoperasi, kelestarian lingkungan hidup, perencanaan sehat. Kegiatan PKK merupakan bagian dari pembangunan nasional yang terus menerus selaras dengan dinamika pembangunan. Kegiatan PKK di daerah merupakan bagian integral dari kegiatan PKK secara nasional, yang dilaksanakan secara serasi dan terpadu di setiap 
Propinsi, Kabupaten/Kota. Kecamatan, Desa/Kelurahan sampai kelompokkelompok PKK dan Dasawisma. Gerakan PKK tetap memelihara hubungan konsultatif, koordinatif dengan tetap memperhatikan hirarki di seluruh jenjang TP PKK. Sistem perencanaan dimulai dari bawah (bottom-up planning system). Hal ini menjadi ikatan yang kuat antar semua jajaran Gerakan PKK dari pusat sampai kelompok - kelompok Dasawisma. Peranan PKK dalam melaksanakan programnya mempunyai kebijakan, strategi yang disesuaikan dengan kebutuhan dalam upaya peningkatan kualitas hidup dan kesejahteraan keluarga. Pelaksanaan program dan kegiatan PKK secara terpadu dilaksanakan oleh pokjapokja dengan berpedoman pada 10 program pokok PKK.

Di tinjau dari mata pencaharian utama masyarakat di Desa Ratna Chaton kecamatan Seputih Raman Kabupaten Lampung Tengah adalah sebagai petani. Ketidakberdayaan mereka dalam factor ekonomi di dalam kehidupan sehari hari diakibatkan oleh penghasilan yang tidak menentu dan cenderung kecil. Upaya PKK yang dilakukan dalam pemberdayaan ekonomi rumah tangga Muslim termasuk ke dalam pokja II yaitu pendidikan dan keterampilan, program UPPK, pengembangan kehidupan berkoperasi. Di Kecamatan Seputih Raman yaitu di Desa Ratna Chaton berusaha untuk menggerakkan partisipasi masyarakatnya dengan melibatkan wadah Pemberdayaan dan Kesejahteraan Keluarga (PKK). Desa Ratna Chaton menjadi salah satu desa yang ada dikecamatan Seputih Raman yang terus melaksanakan program PKK, dan terus memberdayakan perempuan lewat program di dalamnya, dengan tujuan untuk menggerakkan partisipasi masyarakat desa. Lewat program-program yang dilaksanakan oleh PKK di Desa Ratna Chaton, peneliti lebih menitik beratkan pada program pemberdayaan ekonomi yang ada dalam program PKK, yaitu termasuk ke dalam pokja II mengelola program pendidikan dan keterampilan dan pengembangan kehidupan berkoperasi atau Usaha Peningkatan Pendapatan Keluarga (UPPK)

Dalam Pokja II didalamnya terdapat program peningkatan pendapatan keluarga (UP2K). Program UP2K adalah untuk meningkatkan pendapatan ekonomi keluarga. Cara pengembangan usaha perkembangan UP2K adalah dengan pengguliran dana dan penambahan modal usaha, mengupayakan pemasaran UP2K PKK melalui pasar, warung, ikut pada pameran, bazar baik lokal maupun nasional dan menjalin kemitraan dengan Dekranas/Dekranasda, memotivasi keluarga agar mau menjadi anggota koperasi untuk meningkatkan pendapatan keluarga. (Tim Penggerak PKK Pusat,2010:11) Program pemberdayaan ekonomi ini meliputi tahapan penyuluhan, pelatihan kewirausahaan, peminjaman modal usaha dan pengembangan usaha produktif rumah tangga, tahapan pengembangan dan pembinaan tenaga terampil yang dimiliki keluarga dan tahapan pembentukan kelompok sosial serta pengamalan fungsi keluarga sejahtera. Artinya bahwa disamping dilakukan pengembangan kreativitas SDM juga ditumbuhkan kemampuan untuk mengelola usaha-usaha industri rumah tangga.

\section{Konsep Pemberdayaan}

Pemberdayaan (empowerment) menurut Ife 1995(dalam Suharto 2010) berasal dari kata "power" (kekuasaan atau keberdayaan). Ide utama pemberdayaan bersentuhan dengan konsep mengenai kekuasaan. Kemudian 
pemberdayaan bertujuan untuk meningkatkan kekkuasaan orang-orang yang leah atau tidak beruntung.

Menurut Mubyarto (1996:37), pemberdayaan adalah merupakan upaya untuk meningkatkan kemampuan masyarakat dengan cara mengembangkan dan mendinamisasikan potensinya bertolak dari hal itu, tidak hanya ekonomi yang meningkat tapi juga harkat, martabat, rasa percaya diri dan harga diri.

Sedangkan menurut Suhendra (2006:74-75) pemberdayaan adalah suatu kegiatan yang berkesinambungan, dinamis,secara sinergis mendorong keterlibatan semua potensi yang ada secara evolutif dengan keterlibatan semua potensi.

Dalam perspektif islam, menurut Machendrawaty dan Ahmad Safei (2001:42), adalah jelas bahwa Islam pada dasarnya merupakan agama pemberdayaan. Dalam pandangan Islam, pemberdayaan harus merupakan gerakan yang berkesinambungan, sesuai dengan paradigm Islam itu sendiri sebagai agama gerakan dan perubahan. Dengan demikian, pemberdayaan masyarakat pada dasarnya adalah suatu metode pekerjaan sosial dan gerakan sosial tujuannya untuk memperbaiki kualitas hidup manusia melalui pendayagunaan sumber-sumber yang ada pada masyarakat serta menekankan pada prinsip-prinsip partispasi sosial. (Edi Suharto,2006:37)

Proses pemberdayaan masyarakat miskin menurut Pranarka dan Moeldjarto(1996), dapat dilakukan secara bertahap dalam tiga fase yaitu : pertama, fasefinansial. semua proses pemberdayaan berasal dari pemerintah oleh pemerintah dan diperuntukkan bagi rakyat. Kedua, fase partisipatoris adalah proses pemberdayaan dari pemerintah bersama masyarakat yang sudah dilibatkan secara aktif untuk menuju kemandirian. Ketiga, fase emansipatif, adalah proses pemberdayaan dari rakyat dan untuk rakyat dan didukung pemerintah bersama rakyat. Paradigma pemberdayaan tersebut akan mendorong kemampuan pemberdayaan perempuan untuk memperoleh hak-hak ekonomi, sosial dan politik daam meningkatkan kemandirian perempuan.

\section{Ekonomi Rumah Tangga}

Ekonomi berasal dari bahasa yunani yaitu aikonomia, yang terdiri dari dua kata yaitu aikos yang artinya rumah tangga dan nomos yang artinya mengurus atau mengatur. Jadi, ekonomi berarti aturan-aturan untuk menyelenggarakan kebutuhan hidup manusia didalam rumah tangga rakyat dan negara. (Zainal Abidin Ahmad,1997:30)

Ekonomi menurut Samuelson (2004) adalah suatu cara yang dilakukan oleh manusia dan kelompoknya agar dapat memanfaatkan segala sumber yang terbatas dalam memperoleh setiap komoditi dan menyalurkan ke masyarakat untuk dapat dikonsumsi.

Pengertian rumah tangga menurut Sidi Nazar Bakry (1993), merupakan suatu kumpulan dari masyarakat terkecil yang terdiri dari pasangan suami istri,anak-anak, dan sebagainya.

Kesimpulan dari pendapat diatas Ekonomi Rumah tangga dapat diartikan sebagai upaya dalam memenuhi kebutuhan hidup melalui aktifitasaktifitas yang dilakukan oleh sebuah keluarga agar dapat memenuhi kebutuhan primer dan sekunder bagi kehidupan sehari-hari. 


\section{Kesejahteraan Keluarga}

Kesejahteraan keluarga adalah kondisi tentang terpenuhinya kebutuhan dasar manusia dari setiap anggota keluarga secara material, sosial, mental dan spritual sehingga dapat hidup layak sebagai manusia yang bermanfaat.

Secara konseptual, keluarga sejahtera selalu bercirikan kemandirian dan ketahanan keluarga yang tinggi. Kemandirian keluarga yang dimaksud adalah sikap mental dalam hal berupaya meningkatkan kepedulian masyarakat dalam pembangunan, mendewasakan usia perkawinan, membina dan meningkatkan ketahanan keluarga, mengatur kelahiran dan mengembangkan kualitas kesejahteraan keluarga, berdasarkan kesadaran dan tanggung jawab. Yang dimaksud ketahanan dan kesejahteraan keluarga adalah kondisi dinamik suatu keluarga yang memiliki keuletan dan ketangguhan serta mengandung kemampuan fisik-materil guna hidup mandiri dan mengembangkan diri dan keluarganya untuk hidup harmonis dalam meningkatkan kesejahteraan keluarga dengan jumlah anak yang ideal untuk mewujudkan kesejahteraan lahir dan kebahagiaan batin (Bab I pasal 1 ayat (11) UU No. 52 Tahun 2009).

\section{Pemberdayaan dan Kesejahteraan Keluarga (PKK)}

Pemberdayaan dan Kesejahteraan Keluarga (PKK) adalah merupakan gerakan nasional dalam pembangunan masyarakat yang tumbuh dari bawah yang pengelolaanya dari, oleh dan untuk masyarakat menuju terwujudnya keluarga yang beriman dan bertaqwa kepada Tuhan Yang Maha Esa, berakhlaq mulia dan berbudi luhur, sehat sejahtera, maju dan mandiri, kesetaraan dan keadilan gender serta kesadaran hukum dan lingkungan. (Tim Penggerak PKK Pusat,2010:4) PKK atau pemberdayaan dan kesejahteraan keluarga merupakan salah satu program pemerintah yang motor penggeraknya adalah kaum perempuan. Hampir semua daerah memiliki lembaga PKK.

PKK (Pemberdayaan Kesejahteraan Keluarga) merupakan wadah bagi perempuan untuk mengembangkan kemampuan dan potensi yang dimiliki perempuan agar secara mandiri mempunyai keterampilan dan keahlian dalam mengatasi masalah yang mereka hadapi secara mandiri melalui peningkatan kapasitas dan kualitas hidup. Menurut sejarahnya organisasi PKK semula merupakan akronim dari pendidikan kesejahteraan keluarga yang berupaya melibatkan partisipasi dan merupakan program pendidikan perempuan. Selanjutnya pada tanggal 27 Desember 1972 organisasi ini berubah menjadi pembinaan kesejahteraan keluarga yang berupaya tidak hanya mendidik perempuan melainkan membina dan membangun keluarga dibidang mental spiritual dan fisik material serta peningkatan mutu pangan, sandang, papan ,kesehatan dan lingkungan hidup. Selanjutnya dengan adanya reformasi serta paradigma baru dan semangat otonomi daerah, sejak tahun 1999 akronim PKK berubah lagi menjadi Pemberdayaan dan Kesejahteraan Keluarga. (Sejarah PKK,2007)

\section{Hasil Penelitian dan Pembahasan}

Pemberdayaan dan Kesejahteraan Keluarga (PKK) Pemberdayaan dan Kesejahteraan Keluarga (PKK) merupakan Gerakan Nasional dalam pembangunan masyarakat yang tumbuh dari bawah yang pengelolaanya dari, oleh dan untuk masyarakat. Anggota dari PKK adalah ibu - ibu yang telah 
berumah tangga. Dengan keanggotaan perempuan/ibu-ibu dalam PKK maka diharapkan perempuan dapat terberdayakan sehingga mampu membantu kesejahteraan keluarganya.

PKK sendiri mempunyai 10 program pokok, tetapi pada tahap awal didirikan PKK di Desa Ratna Chaton belum semua program di jalankan secara baik mulai satu persatu dijalankan dari 10 program tersebut. PKK (Pemberdayaan Kesejahteraan Keluarga) merupakan wadah bagi perempuan untuk mengembangkan kemampuan dan potensi yang dimiliki perempuan agar secara mandiri mempunyai keterampilan dan keahlian dalam mengatasi masalah yang mereka hadapi secara mandiri melalui peningkatan kapasitas dan kualitas hidup.4

Dari mulai didirikanya PKK hingga sekarang PKK Desa Ratna Chaton Kecamatan Seputih Raman tetap maju dan dari tahun ke tahun PKK Desa Ratna Chaton semakin maju dengan 10 program PKK dan ibu - ibu PKK nya selalu antusias sekali dalam kegiatan- kegiatan program PKK. Salah satu program PKK dalam meningkatkan pendapatan keluarga adalah program UPPK dan Koperasi yang masuk ke dalam POKJA 2 ,UPPK merupakan organisasi yang berada di bawah PKK yang berfungsi untuk meningkatkan kelompok dan kualitas usaha peningkatan pendapatan keluarga (UPPK) dan upaya perbaikan ekonomi keluarga. PKK pada POKJA 2 ini dari tahun ke tahun semakin meningkat dengan melatih ibu - ibu untuk berwirausaha.

\section{Visi dan Misi gerakan PKK}

a. Visi gerakan PKK

Terwujudnya keluarga yang beriman dan bertakwa kepada Tuhan Yang Maha esa, berakhlaq mulia dan berbudi luhur, sehat sejahtera, maju mandiri, kesetaraan dan keadilan gender serta kesadaran hukum dan lingkungan.

b. Misi gerakan PKK

1. Meningkatkan mental spiritual, perilaku hidup dengan menghayati dan mengamalkan pancasila serta meningkatkan pelaksanaan hak dan kewajiban sesuai dengan hak asasi manusia (HAM) demokrasi, meningkatakan kesetiakawanan social dan kegotongroyongan serta pembentukan watak bangsa yang selaras, serasi dan seimbang.

2. Meningkatkan pendidikan dan keterampilan yang diperlukan, dalam upaya mencerdaskan kehidupan bangsa serta meningkatkan pendapatan keluarga.

3. Meningkatkan kualitas dan kuantitas pangan keluarga serta upaya peningkatan pemanfaatan pekarangan melalui halaman asri, teratur dan nyaman ( HATINYA ) PKK, sandang dan perumahan serta tata laksana rumah tangga yang sehat.

4. Meningkatkan derajat kesehatan, kelestarian lingkungan hidup serta membiasakan hidup berencana dalam semua aspek kehidupan dan perencanaan ekonomi keluarga dengan membiasakan menabung.

5. Meningkatkan pengelolaan Gerakan PKK baik kegiatan pengorganisasian maupun pelaksanaan program - programnya yang disesuaikan dengan situasi dan kondisi masyarakat setempat. 


\section{Tujuan PKK}

Tujuan gerakan PKK adalah memberdayakan keluarga untuk meningkatkan kesejahteraan menuju terwujudnya keluarga yang beriman dan bertaqwa kepada Tuhan Yang Maha Esa, berakhlak mulia dan berbudi luhur, sehat sejahtera, maju dan mandiri, kesetaraan dan keadilan gender serta kesadaran hukum dan lingkungan, menjadi sangat relevan untuk mengatasi berbagai kemelut persoalan keluarga, apapun bentuknya.

Hal ini mengingat, kesejahteraan keluarga yang dimaksud adalah keluarga yang sehat, bahagia dan sejahtera lahir batin. PKK bertujuan untuk menumbuhkan, menghimpun, mengarahkan, dan membina keluarga guna mewujudkan keluarga sejahtera. Pemberdayaan perempuan dengan mengoptimalkan peran PKK juga diharapkan mampu memberikan penguatan perempuan dalam bidang ekonomi sehingga perempuan memiliki usaha alternatif yang akan melepaskannya dari tekanan ekonomi di tengah kesulitankesulitan krisis yang membelitnya.

\section{Tujuan UPPK}

Tujuan umum UPPK adalah untuk membina dan mengembangkan kegiatan usaha keluarga yang bergabung dalam kelompok atau perorangan sehingga secara bertahap mampu menjadi wiraswasta serta memungkinkan kegiatan yang bersifat koperatif. Sedangkan tujuan khusus UPPK adalah sebagai berikut:

Pertama, membantu modal usaha bagi usaha ekonomi lemah untuk menumbuhkan kewirausahaan. Kedua, membantu pengembangan usaha bagi usaha yang membutuhkan penambahan modal, Ketiga, menumbuhkembangkan kegiatan usaha yang bersifat koperatif untuk memperkokoh KUD.8

\section{Program Kerja UPPK}

Program UPPK ( Usaha peningkatan pendapatan keluarga ) Desa Ratna Chaton adalah :

1. Pembinaan Life Skill Ekonomi Keluarga

Pembinaan ini meliputi penyuluhan, pelatihan kewirausahaan, dan pengembangan usaha rumah tangga. Penyuluhan dan pelatihan biasanya datang dari Dinas Kabupaten BKP ( Badan Ketahanan Pangan ).

2. Pertemuan Rutin diadakan secara bergiliran dirumah anggota yang bertujuan untuk memperat kerjasama selain itu juga membicarakan tentang program yang telah dilaksanakan serta program kerja yang akan dilaksanakan. Pertemuan rutin ini biasannya diadakan 2 minggu 1 kali.

3. Arisan Keluarga . Program ini dilakukan untuk meningkatkan persaudaraan dan ajang kumpul sekaligus wadah untuk menambah modal usaha. Arisan keluarga boleh diikuti oleh seluruh pengurus, anggota dan keluarga partisipan kelompok UPPK Desa Ratna Chaton.

4. Mengikuti pameran - pameran atau bazar tingkat Desa, Kecamatan, Kabupaten dan Propinsi. Kegiatan ini adalah memamerkan dan promosi hasil karya usaha UPPK Desa Ratna Chaton.

5. Mengikuti Perlombaan. Perlombaan ini dilakukan tingkat Desa, Kabupaten dan Propinsi. 


\section{Implementasi Program Kerja UPPK-PKK}

Program UPPK(Usaha Peningkatan Pendapatan Keluarga) merupakan salah satu upaya untuk meningkatkan kesejahteraan dan ketahanan keluarga yang dicerminkan oleh meningkatnya kemampuan keluarga dalam memenuhi kebutuhan keluarga, untuk menggali sumber-sumber kemampuan masyarakat untuk meningkatkan pendapatan keluarga. Program ini dilakukan melalui peningkatan pemberdayaan keluarga dalam bidang usaha ekonomi produktif. Tujuannya kegiatan tersebut untuk meningkatkan pendapatan melalui kelompok usaha ekonomi produktif dalam bentuk usaha secara perseorangan maupun kelompok. Program ini termasuk di bawah pembinaan dan bimbingan POKJA 2. Di dalam program UPPK bertugas membina ibu - ibu PKK dalam hal peningkatan ekonomi.

Tahap pelaksanaan merupakan salah satu tahap yang paling penting dalam program pemberdayaan, karena sesuatu yang sudah direncanakan dengan baik akan dapat melenceng dalam pelaksanaan dilapangan bila tanpa ada kerja sama antar petugas dan masyarakat, dalam tahap pelaksanaan yang dilakukan oleh UPPK-PKK adalah membuat sebuah program, berdasarkan hasil penelitian program UPPK-PKK Desa Ratna Chaton dalam pemberdayaan ekonomi rumah tangga pelaksanaan kegiatanya adalah sebagai berikut:

a. Pelatihan Menumbuhkan Jiwa Kewirausahaan. Pelatihan ini dimaksudkan agar masyarakat (ibu rumah tangga) termotivasi untuk berwiarausaha, menumbuhkan jiwa kewiraushaan dan dapat memulai dari proses pengenalan yang inten terhadap kemampuan dan potensi dirinya, potensi lingkungan dan sekitarnya dan dari pelatihan tersebut dapat menghasilkan atau ibu rumah tangga langsung action melaksanakan apa yang didapat di pelatihan tersebut (mengembngkan usaha produktif rumah tangga). Partisipasi dan kesungguhan peserta sangat baik. Hal ini dilihat dari kesungguhan peserta dalam mengikuti demonstrasi maupun praktek. Hal ini didukung dengan kesempatan yang diberikan kepada peserta untuk praktek dan membawa pulang hasil tersebut. Dengan diadakan pelatihan kewiarusahaan ini diharapkan ilmu yang diberikan dapat diamalkan dalam bentuk pengembangan usaha

Ibu Wiwik selaku ketua PKK selalu memotivasi ibu-ibu untuk selalu mengikuti kegiatan dan memotivasi untuk semangat mengembangkan usaha.

Tujuan pelatihan kewirausahaan adalah :

1. Untuk menumbuhkan jiwa kewirausahaan ibu - ibu rumah tangga dalam mengembangkan usaha produktif rumah tangga.

2. Mengembangkan potensi dan kreatifitas warga masyarakat Ratna Chaton untuk mengatasi berbagai problem perekonomian guna meningkatkan taraf hidup yang lebih baik.

3. Meningkatkan produktifitas Industri Rumah Tangga (UKMM) warga di Desa Ratna Chaton.

4. Menimbulkan minat usaha mandiri (wirausaha) untuk meningkatkan pendapatan keluarga dan melatih kemandirian

b. Peminjaman Modal. Bagi ibu-ibu anggota UPPK yang tidak memilki modal untuk membuka usaha, UPPK memberikan bantuan peminjaman 
modal untuk ibu-ibu yang ingin membuka usaha. Peminjaman dari UPPK adalah peminjaman yang cepat,mudah dan dengan biaya rendah.

c. Pengembangan Usaha Produktif Rumah Tangga. Usaha merupakan kegiatan pemberdayaan ekonomi yang dikembangkan oleh keluarga melalui keahlian atau kemampuan yang dimilikinya, untuk menambah penghasilan ekonomi rumah tangga. Usaha usaha nya adalah seperti usaha pembuatan keripik usus, usaha pembuatan keripik kulit ayam, usaha pembuatan kerupuk rambak, usaha pembuatan rengginang singkong(eyek-eyek), dan usaha pembuatan sari jamu.

\section{Tingkat keberhasilan}

Dari hasil penelitian ini sesuai dengan apa yang dikatakan Schuler, Hashemi dan Riley indicator pemberdayaan yaitu kemampuan individu untuk membeli barang- barang kebutuhan keluarga sehari-hari, Kemampuan membeli komoditas besar : kemampuan individu untuk membeli barang- barang sekunder atau tersier, seperti lemari pakaian, TV, radio, Koran, majalah,pakaian keluarga, Terlibat dalam pembuatan keputusan rumah tangga: mampu membuat keputusan-keputusan secara sendiri maupun bersama suami/istri mengenai keluarga.

Menurut Edi Suharto hasil pemberdayaan dapat dilihat dari : Pertama, Memenuhi kebutuhan dasarnya sehingga mereka memiliki kebebasan (freedom), dalam arti bebas dari kebodohan, bebas dari kesakitan. Kedua, menjangkau sumber-sumber produktif yang memungkinkan mereka dapat meningkatkan pendapatannya dan memperoleh barang-barang dan jasa-jasa yang mereka perlukan. Ketiga, berpartisipasi dalam proses pembangunan dan keputusankeputusan yang mempengaruhi mereka.

Menurut penelitian tingkat keberhasilan PKK pada program UPPK ibu rumah tangga adalah : Meningkatnya taraf hidup. Anggota PKK pada program UPPK Desa Ratna Chaton menjadi mandiri, mereka tidak bergantung kepada suami bahkan terdapat anggota yang menjadi tulang punggung keluarga. Dengan demikian ibu rumah tangga yang tergabung di program UPPK menjadi terangkat harkat dan martabatnya, serta menjadi meningkat taraf hidupnya. Dalam sebuah program yang berorientasi pada peningkatan kesejahteraan hidup salah satunya adalah dengan memberdayakan ekonomi. Indikasi dari keberhasilan suatu program berdasarkan terpenuhinya kebutuhan hidup. Kebutuhan hidup yang tidak hanya bersifat primer namun kebutuhan yang bersifat sekunder dan tersier dapat tercukupi. Tingkat keberhasilan program UPPK yaitu bertambahnya pendapatan ibu-ibu rumah tangga, memberikan usaha baru bagi ibu-ibu rumah tangga.

Berdasarkan hasil dari penelitian dilapangan, bahwa Implementasi PKK dalam pemberdayaan eknomi rumah tangga di Desa Ratna Chaton Kecamatan Seputih Raman dikatakan cukup baik. Dalam hal ini juga dibenarkan oleh anggota PKK Desa Ratna Chaton itu sendiri bahwa kegiatan-kegiatan tersebut aktif dijalankan kemudian yang dilakukan Ketua PKK sudah dilakukan semaksimal mungkin dalam pemberian pembinaan (pendidikan dan pelatihan) serta senantiasa selalu mengajak ibu-ibu Desa Ratna Chaton beserta anggotanya untuk terus ikut serta dalam kegiatan-kegiatan yang dilakukan setiap Pokja. Serta dibenarkan pula oleh warga Desa Ratna Chaton sendiri bahwa PKK Desa 
Ratna Chaton telah melakukan usaha didalam pembinaan (pendidikan dan pelatihan) semaksimal mungkin untuk menunjang pendapatan ekonomi masyarakat di Desa Ratna Chaton itu sendiri.

Kemudian berdasarkan hasil penelitian bahwa pendapatan yang dihasilkan kelompok UPPK cukup membantu dalam meningkatkan pendapatan ekonomi rumah tangga. Adapun pengertian pendapatan keluarga yang sering kita artikan secara umum adalah penerimaan suatu rumah tangga baik yang diperoleh kepala rumah tangga ataupun istri yang akan dipergunakan untuk memenuhi kebutuhan hidup. Dengan definisi diatas, maka setiap keluarga akan berbeda tingkat pendapatannya.

Jika dikaitkan dengan pemberdayaan keluarga, maka berdasarkan hasil penelitain ibu - ibu rumah tangga sekarang ini mendayagunakan kemampuan yang mereka miliki dan berkembang. Banyak ibu rumah tangga mengaku bahwa dengan adanya UPPK sudah banyak mengalami perubahan dan perkembangan. kearah yang lebih baik. Ini menjadi bukti keberhasilan program yang dilaksanakan PKK pada program UPPK POKJA II.

\section{Simpulan}

Pemberdayaan ekonomi rumah tangga adalah merupakan upaya untuk meningkatkan kemampuan masyarakat (rumah tangga Muslim) dengan cara mengembangkan dan mendinamisasikan potensi-potensi atau kemampuan ibu rumah tangga yang mereka miliki. Berdasarkan hasil penelitian dilapangan mengenai Implementasi Program Kerja PKK (Pemberdayaan dan Kesejahteraan Keluarga) dalam pemberdayaan ekonomi rumah tangga di Desa Ratna Chaton Kecamatan Seputih Raman kabupaten Lampung Tengah bahwa program pemberdayaan ekonomi sudah berjalan dengan baik. Pembahasanya telah diuraiakan dalam penelitian ini penulis menarik kesimpulan yaitu:

Implementasi program pemberdayaan ekonomi antara lain : Pertama, Pelatihan kewirausahaan. Pelatihan berjalan dengan baik dan masyarakat(ibu rumah tangga) antusias dalam mengikutinya. Tujuan pelatihan ini untuk memotivasi ibu rumah tangga untuk berwirausaha. Kedua, Peminjaman modal untuk mengembangkan usaha. Ketiga ,Pengembangan usaha produktif rumah tangga, Usaha usaha nya adalah seperti usaha pembuatan keripik usus, usaha pembuatan keripik kulit ayam, usaha pembuatan kerupuk rambak, usaha pembuatan rengginang singkong(eyek-eyek), dan usaha pembuatan sari jamu.

Tingkat keberhasilan PKK dalam pemberdayaan ekonomi rumah tangga adalah meningkatnya taraf hidup Ibu rumah tangga dapat mandiri dengan mengembangkan usahanya dan dapat menghasilkan pendapatan ekonomi rumah tangga.

\section{Referensi}

Cholid Narbuko,Abu Achmadi,Metodologi Penelitian, (Jakarta: Bumi Aksara:1997) Departemen RI, Al-Qur'an Terjemah Indonesia, (Jakarta : P.T Sari Agung , 2005)

Didin Hafidhuddin, Dakwah Aktual, (Jakarta: Gema Insani,1998)

Edi Suharto, Membangun Masyarakat Memberdayakan Rakyat, (Bandung : PT Refika Aditama, 2005), Cet ke - 1.

Edi Suharto, Metodelogi Pengembangan Masyarakat: Jurnal comev, (Jakarta :BEMJ,PMI,2004) 
Hamzah Ya'qub, Etos Kerja Islami "Petunjuk Pekerjaan Yang Halal dan Haram dalam Syariat Islam", (Jakarta : Pedoman Ilmu Jaya,1990)

Harry Hikmat, Strategi Pemberdayaan Masyarakat, (Bandung : Humaniora, 2004)

Henry Faisal, Ekonomi Media, (Jakarta : PT. Raja Grafindo, 2010), Cet ke-1

Irawan Soehartono, (1995). Metode Penelitian Sosial Suatu Teknik penelitian Bidang Kesejahteraan Sosial dan Ilmu Sosial lainnya, (Bandung : PT remaja Rosdakarya, 1995), Cet -ke1

Ismail Nawawi, Ekonomi Islam, (CV. Surabaya : Putra Media Nusantara,2009)

Jalaludin Rahmat,Metode Penelitian Komunikasi, (Bandung : Remaja Rosda karya,1984)

Jim Ife Frank Tesoriero, Community Development, (Yogyakarta :Pustaka Pelajar, 2008)

Koentjaningrat, Metode Penelitian Masyarakat, (Jakarta : Gramedia,1981)

Lexy. J Moleong, Metodologi Penelitian Kualitatif, (Bandung : Remaja Rosdakarya,2013)

M. Ali Hasan,Pedoman Hidup Berumah Tangga Dalam Islam, (Jakarta : Siraja,2006)

Mubyarto, Ekonomi Rakyat, Program IDT dan Demokrasi Indonesia, (Yogyakarta : Aditya Media, 1996)

Muhammad Amin, Konsep Masyarakat Islam Upaya Mencari Identitas Dalam Era Modernisasi,( Jakarta : Fikahati Aneska, 1992)

Muhammad Musa, Metodologi Penelitian,( Jakarta : Fajar Agung, 1988)

Nana Sudjana, Tuntunan Penyusunan Karya Ilmiah, (Bandung: Alumni,1998)

Nanih Mahendrawati dan Agus Ahmad Syafe'I, "Pengembangan Masyarakat Islam", (Bandung : Remaja Rosda Karya,2001)

Pranarka dan Moeldjarto, Pemberdayaan (Empowerment) dalam Pembedayaan,Konsep Kebijakan dan Implementasi,( Jakarta : CSIS, 1996)

Samuelson, Paul A. dan Nordhaus William D,Ilmu Makro Ekonomi. (Jakarta: PT Media Global Edukasi,2004)

Sugiyono, Metode Penelitian Kuantitatif dan Kualitatif Dan RED, Bandung: Alfabeta,2012)

Suharismi Arikunto, Dasar - Dasar Research, (Bandung : Tarsoto,1995)

Suharto, Membangun Masyarakat Memberdayakan Rakyat Kajian Strategis Pembangunan Kesejahteraan Sosial dan Pekerjaan Sosial,(Bandung: PT. Rafika Aditama,2004)

Supriyati Istiqomah, Dasar - Dasar Pengembangan Masyarakat Islam, (Bandar Lampung : Fakultas Dakwah,2008)

Tim Penggerak PKK Pusat, (2010). Pemberdayaan Dan Kesejahteraan PKK, Jakarta : Tim Penggerak Pusat.

Totok Mardikanto, Pemberdayaan Masyarakat, Alfabeta, (Bandung : CV. Abdi,2012)

Undang-Undang No. 52 Tahun 2009 tentang Perkembangan Kependudukan dan Pembangunan Keluarga Sejahtera.

Zubaedi, Pengembangan Masyarakat( wacana dan praktek), (Jakarta: Kencana Prenada Media, 2013), Cet ke-1 